\title{
Platelet activation: Ultrastructure and morphometry in platelet-rich plasma of horses ${ }^{1}$
}

\author{
Bruna M. Zandim², Maria V. de Souza ${ }^{3 *}$, Pablo C. Magalhães ${ }^{3}$, Laércio dos A. Benjamin ${ }^{3}$, \\ Leandro $\mathrm{Maia}^{4}$, Aécio C. de Oliveira ${ }^{3}$, José de 0 . Pinto ${ }^{3}$ and José I. Ribeiro Júnior ${ }^{5}$
}

\begin{abstract}
Zandim B.M., Souza M.V., Magalhães P.C., Benjamin L.A., Maia L., Oliveira A.C., Pinto J.O. \& Ribeiro Júnior J.I. 2012. Platelet activation: Ultrastructure and morphometry in platelet-rich plasma of horses. Pesquisa Veterinária Brasileira 32(1):83-92. Departamento de Veterinária, Universidade Federal de Viçosa, Campus Universitário s/n, Viçosa, MG 36570-000, Brazil. E-mail: msouza@ufv.br

This study was conducted to investigate the activation ability of the platelet-rich plasma (PRP) by pharmacological agents, as well as to verify the need or not of this activation for therapeutic use. The PRP was obtained from four healthy crossbred geldings aged 13 to 16 years (15 \pm 1 years), and was processed for observation and quantification of the platelet morphology by using the transmission electron microscopy. All PRP samples were activated with $10 \%$ calcium chloride $\left(\mathrm{CaCl}_{2}\right)$ solution, pure bovine thrombin or associated with $\mathrm{CaCl}_{2}$. The control (pure PRP) was not pharmacologically activated. In the pure PRP samples, $49 \%$ of the platelets were classified as state of activation uncertain, $41 \%$ as resting, $9 \%$ as fully activated and $1 \%$ as irreversibly damaged. Treatment with $10 \% \mathrm{CaCl}_{2}$ provided a distribution of $54 \%$ platelets in state of activation uncertain, $24 \%$ as fully activated, $20 \%$ as resting, and $2 \%$ as irreversibly damaged. The platelet morphology of the bovine thrombin treated samples did not fit into classification adopted, as showing irregular shape with emission of large filamentous pseudopods, appearance of ruptured and whole granules in the remaining cytoplasm and extracellular environment. There was effect of the treatment on the platelet morphology $(\mathrm{P}=0.03)$. The $10 \% \mathrm{CaCl}_{2}$ is an adequate platelet-activating agent. However, in cases the use of PRP under its liquid form is necessary, the use of pure PRP is recommended, since besides presenting an adequate percentage of fully activated platelets it also has significant amount of the resting type, which can be activated by substances found in the injured tissue.
\end{abstract}

INDEX TERMS: Plasma rich in platelets, platelet function, growth factors, horses.

RESUMO.- [Ativação plaquetária: ultraestrutura e morfometria no plasma rico em plaquetas de equinos.] 0 objetivo desse estudo foi investigar a capacidade de ati-

\footnotetext{
${ }^{1}$ Received on July 4, 2011.

Accepted for publication on October 24, 2011.

${ }^{2}$ Rua Pedro Autran 130, Centro, Itambacuri, MG 39830-000, Brasil. buiazandim@hotmail.com

${ }^{3}$ Departamento de Veterinária, Universidade Federal de Viçosa (UFV), Campus Universitário s/n, Viçosa, MG 36570-000, Brazil. * Corresponding author:msouza@ufv.br

${ }^{4}$ Doutorando do Departamento de Clínica Veterinária, Faculdade de Medicina Veterinária e Zootecnia, Universidade Estadual Paulista (Unesp), Campus Universitário s/n, Botucatu, SP 18616-9700, Brazil. E-mail: leandromvet@hotmail.com

${ }^{5}$ Departamento de Estatística, UFV, Campus Universitário s/n, Viçosa, MG.E-mail: jivo@ufv.br
}

vação do plasma rico em plaquetas (PRP) por substâncias farmacológicas, assim como verificar a necessidade ou não dessa ativação para uso terapêutico. O PRP foi obtido de quatro equinos mestiços hígidos, machos castrados, com 13 a 16 anos ( $15 \pm 1$ anos) de idade, e processado para observação e quantificação da morfologia plaquetária mediante a utilização da microscopia eletrônica de transmissão. Todas as amostras de PRP foram ativadas com cloreto de cálcio $\left(\mathrm{CaCl}_{2}\right)$ a $10 \%$, trombina bovina pura ou associada a $\mathrm{CaCl}_{2}$. $\mathrm{O}$ controle (PRP puro) não foi ativado farmacologicamente. Nas amostras de PRP puro, $49 \%$ das plaquetas foram classificadas como ativação incerta, $41 \%$ em repouso, $9 \%$ totalmente ativada e $1 \%$ com dano irreversível. 0 tratamento com $\mathrm{CaCl}_{2}$ a $10 \%$ proporcionou uma distribuição de $54 \%$ de plaquetas com ativação incerta, $24 \%$ totalmente 
ativada, $20 \%$ em repouso, e $2 \%$ como com dano irreversível. Amostras tratadas com trombina bovina apresentaram morfologia plaquetária que não se enquadraram na classificação adotada, apresentando forma irregular com emissão de grandes pseudópodes filamentosos, aspecto de rompimento e grânulos inteiros no citoplasma remanescente e meio extracelular. Houve efeito do tratamento sobre a morfologia plaquetária $(\mathrm{P}=0,03) .0 \mathrm{CaCl}_{2}$ a $10 \%$ é um adequado agente ativador de plaquetas. Entretanto, nos casos onde se faz necessário o uso de PRP na forma mais líquida, recomenda-se o uso do PRP puro, que além de apresentar uma adequada porcentagem de plaquetas totalmente ativadas, também possui importante quantidade do tipo em repouso, que pode ser ativado por substâncias presentes no tecido lesionado.

TERMOS DE INDEXAÇÃO: Componentes ricos em plaquetas, função plaquetária, fatores de crescimento, microscopia eletrônica de transmissão, equinos.

\section{INTRODUCTION}

The platelet-rich plasma (PRP) and the platelet concentrate (PC, solid composition of platelets without plasma) which are used in both in vitro and in vivo studies constitute a line of research still under development for researchers, the reason why they are little clinically used by clinicians in equine species. Platelets are anucleate cytoplasmic fragments (Pretorius et al. 2007, Alsousou et al. 2009, Blair \& Flaumenhaft 2009) derived from megakaryocytes, with approximately $1-3 \mu \mathrm{m}$ diameter (Harrison \& Cramer 1993, Everts et al. 2006a, Pretorius et al. 2007, Alsousou et al. 2009), and have fundamental role in haemostasis (Harrison \& Cramer 1993, Everts et al. 2006a, Blair \& Flaumenhaft 2009). Normally, they circulate under the resting form (Everts et al. 2006a) that provides discoid appearance (Everts et al. 2006a,Blair \& Flaumenhaft 2009), due to structure of the cytoskeleton composed of microtubules and both actin and myosin microfilaments (Blockmans et al. 1995, Everts et al. 2006a), and cytoplasm containing mitochondria, dense tubular system, open canalicular system, glycogen particles, lysosomes, peroxisomes as well as the platelet-specific storage granules ( $\alpha$-granules and dense bodies) (Harrison \& Cramer 1993, Blockmans et al. 1995. Freson et al. 2007, Pretorius et al. 2007, Alsousou et al. 2009, Blair \& Flaumenhaft 2009). In transmission electron microscopy, the $\alpha$-granules appear as oval to spherical bodies covered by membrane with the electron-denser interior, as being less electron-dense (darker) than the dense granules (Wurzinger \& Schimid-Schönbein 1990). The platelets are covered by membrane constituted by phospholipid bilayer, polysaccharides and glycoproteins (Blockmans et al. 1995), from which the structural arrangement allows this corpuscle to quickly respond to stimuli and changes in the environment (Schick \& Yu 1974, Wurzinger \& SchimidSchönbein 1990, Camera et al. 1999, Furlan 2002).

The platelets can be activated by physiological or pharmacological agents. Once they are activated, the platelets show morphological change from the discoid shape to round one and develop pseudopods that spread through the injured tissue, a phenomenon so-called platelet aggregation (Everts et al. 2006a). Additionally, the degranulation of their granules occurs (Blockmans et al. 1995, Frechette et al. 2005, Everts et al. 2006a). After agonist stimulation, the platelet $\alpha$-granules release proteins by at least two mechanisms: via fusion with the open canalicular system and subsequent extrusion of its contents through small channels in the plasmatic membrane (White \& Krumwiede 1987, Escolar \& White 1991, Rendu \& Brohard-Brohn 2001 , Reed 2004) or by exocytosis, that is, for direct fusion of the $\alpha$-granules with the plasmatic membrane (Sims et al. 1988).

The release of the $\alpha$-granule proteins in the lesion site promotes the recruitment of other platelets, leukocytes and plasmatic proteins (Harrison \& Cramer 1993), as initiating the inflammatory process, besides promoting angiogenesis which results into neovascularization and formation of a new conjunctive tissue necessary to healing (Everts et al. 2006a, Blair \& Flaumenhaft 2009).

The PRP has shown to be a promising therapy for several diseases in animals and human beings, since it is an autogenous and economical source of growth factors (Foster et al. 2009), non-toxic and non-immune reactive (Gonshor 2002, Alsousou et al. 2009), obtained by sequestration and concentration of the platelets by means of a density gradient through centrifugation (Vendramin et al. 2004). It is commonly used under activated form after the addition of activating agents such as ADP (Rinder et al.1991), thrombin (Aspenberg \& Virchenko 2004, Ouyang \& Qiao 2006, Silva et al. 2007, Waselau et al. 2008), Thromboplastin (Filgueiras 2008), collagen (Murray et al. 2006, 2007, Fufa et al. 2008), calcium chloride (Anitua et al. 2004, Giacco et al. 2006, Gimeno et al. 2006, Carmona et al. 2007, Argüelles et al. 2008, De Mos et al. 2008, Maia et al. 2009a,b, De Vos et al. 2010), calcium gluconate (Kitoh et al. 2004) or the combination of two of them, such as bovine thrombin and calcium chloride (Everts et al. 2006b, Gandhi et al. 2006, Virchenko \& Aspenberg et al. 2006, Fufa et al. 2008, Monteiro et al. 2009), besides thromboxane, platelet activating factor, serotonin, epinephrine and cyclic endoperoxide analogues (Furlan 2002, Everts et al. 2006a, Blair \& Flaumenhaft 2009). However, it is believed the PRP to release growth factors without requiring exogenous induction of the platelet activation (McCarrel \& Fortier 2009), as being already used in some research without prior activation for the treatment of musculoskeletal, tendon and ligament disorders in horses (Sutter et al. 2004, Smith et al. 2006, Schnabel et al. 2007, Bosch et al. 2009, McCarrel \& Fortier 2009) and other species (Mishra \& Pavelko 2006, Kajikawa et al. 2008, De Vos et al. 2010).

In this context, the lack of a comparative study revealing the morphology of platelets in the platelet-rich plasma activated with the most commonly used activating agents led to the need for accomplishing this experiment, whose objective was to evaluate, through an ultrastructural and morphometric study, the ability of PRP activation with $10 \%$ calcium chloride $\left(\mathrm{CaCl}_{2}\right)$ solution, bovine thrombin or the association of both. In addition, this research aimed to verify the need for activation, or not, of the PRP for therapeutic 
use, based on the results obtained in the PRP not pharmacologically activated. The formulated hypothesis according to the proposed methodology is that the not pharmacologically activated platelet-rich plasma presents important platelet activation, which is essential to the release of growth factors.

\section{MATERIALS AND METHODS}

This research was approved by the Ethics Committee of the Department of Veterinary Medicine, Federal University of Viçosa (Process number 34/2009). The assays are in accordance with the Veterinary Professional Ethics Code, the Ethical Principles for Animal Research established by the Brazilian College for Animal Experimentation, and current Brazilian legislation.

Four crossbred healthy geldings aged from 13 to 16 years (15 \pm 1 years) and weighing between 270 and $297 \mathrm{~kg}(285 \pm 13.59$ $\mathrm{kg}$ ) were used. During the selection process, aiming to ensure the good health, all animals were submitted to both general physical examination (heart and respiratory rates, capillary refill time, rectal temperature, mucous membrane color, hydration and intestinal motility) and laboratory tests [complete blood count and determination of the fibrinogen and total plasma proteins (TPP)].

Thirty days before beginning the research, the horses remained in individual stalls and were fed tifton 85 (Cynodon nlemfuensis) hay, elephant grass (Pennisetum purpureum) and ration (Total Alimentos S/A, Três Corações, MG, Brazil). The mineral salt (Nutrihorse plus ${ }^{\circledR}$, Nutriplan, Juiz de Fora, MG, Brazil) and water were left ad libitum.

Two weeks prior to obtaining the PRP, the animals were weighed, bathed with insecticide (Ultimate ${ }^{\circledR}$, Pffizer Saúde Animal, Belo Horizonte, MG, Brazil) and were orally dewormed with moxidectin paste (Equest ${ }^{\circledR}$, Fort Dodge, Mogi Mirim, SP, Brazil) at a single dose of $0.2 \mathrm{mg} / \mathrm{kg}$ orally for elimination of the endo- and ectoparasites. During the same period, complete blood counts, as well as the determination of the TPP and fibrinogen concentrations were again accomplished.

Based on the method described by Argüelles et al. (2006), some modifications were made in order to obtain the PRP. For this purpose, $81 \mathrm{~mL}$ blood samples were collected from each animal by puncturing the external jugular vein in 18 vacutainer tubes $(0.5 \mathrm{~mL}$ anticoagulant and $4.5 \mathrm{~mL}$ whole blood) with $3.8 \%$ sodium citrate $(0.199 \mathrm{~mol} / \mathrm{L})$ (Becton Dickinson Indústrias Cirúrgicas Ltda, Juiz de Fora, MG, Brazil). In addition, another $4.5 \mathrm{~mL}$ of whole blood were collected in EDTA-containing tube (Becton Dickinson Indústrias Cirúrgicas Ltda, Juiz de Fora, MG, Brazil) for counting blood platelet, which was automatically performed $\mathrm{CH}-$ maCount plus, Human of Brazil, Recife, PE, Brazil).

The blood samples obtained with sodium citrate were homogenized and centrifuged at $120 \mathrm{~g}$ for $5 \mathrm{~min}$. From each centrifuged tube, $50 \%$ supernatant column was disregarded in order to use a plasma from which the platelet concentration was higher in the second centrifugation.

From the plasma remaining in those 18 tubes, $1.1 \mathrm{~mL}$ were pipetted near the leukocyte layer, so totalizing $20 \mathrm{~mL}$ that were placed in two sterile polypropylene tubes without anticoagulant (Becton Dickinson Indústrias Cirúrgicas Ltda, Juiz de Fora, MG, Brazil) with $10 \mathrm{~mL}$ capacity. Following, new centrifugation at $240 \mathrm{~g}$ for 5 min was accomplished. After this second centrifugation, the plasma showed to be divided into two fractions: the supernatant (platelet-poor plasma) and the remaining fraction so-called as platelet-rich plasma. Finally, an approximate volume of $75 \%$ plasma from each tube was disregarded and a total of $5 \mathrm{~mL}$ PRP were conditioned in a new sterile tube without anticoagulant. A $10 \mu \mathrm{L}$ fraction was used for manual counting of platelets (Rees \& Ecker 1923), since the automatic counting would be prejudiced or even impossible due to existence of platelet clusters in PRP.

For activation, $0.9 \mathrm{~mL}$ PRP aliquots were pipetted into four new sterile tubes. The activation was performed by adding $50 \mu \mathrm{L}$ of $10 \% \mathrm{CaCl}_{2}$ (Calcium Chloride $11.1 \%, 1 \mathrm{M}^{\circledR}$, Sigma-Aldrich Brasil Ltda, São Paulo, SP, Brazil) (Argüelles et al. 2008), 50 $\mu \mathrm{L}$ (20 IU) of bovine thrombin (Bovine thrombin lyophilized powder, 59 NIG units $/ \mathrm{mg}^{\circledR}$, Sigma-Aldrich Brasil Ltda, São Paulo, SP, Brazil) diluted into Milli-Q water, as performed by Aspenberg \& Virchenko (2004) and Waselau et al. (2008), or $50 \mu \mathrm{L}$ bovine thrombin (20 IU) diluted in $10 \% \mathrm{CaCl}_{2}$. In the remaining tube, PRP was not activated, but received $50 \mu \mathrm{L}$ of Milli-Q water and was considered as control.

The tubes containing PRP with the activating substances, as well as the pure one (without activation) were conditioned in an oven at 20 to $22^{\circ} \mathrm{C}$ for two hours in order to encouraging the platelet degranulation (Zimmerman et al. 2003, Argüelles et al. 2006, Maia et al. 2009a,b).

The platelet ultrastructure was evaluated in the PRP aliquots activated or not, by using transmission electron microscopy (Zeiss EM9, Zeiss do Brasil Ltda, São Paulo, SP, Brazil; and Tecnai G2-12 Spirit, $80 \mathrm{kV}$, Tecnai, Hillsboro, Oregon, USA), based on the method described by Paes Leme et al. (2006) with some modifications. For this, each tube containing $0.95 \mathrm{~mL}$ PRP received $0.1 \mathrm{~mL}$ glutaraldehyde (Glutaraldehyde EM grade 25\%®, Koch Instrumentos Científicos Ltda, São Paulo, SP, Brazil) at 10\%. Following, the samples were centrifuged at $520 \mathrm{~g}$ for $20 \mathrm{~min}$, as resulting into gelatinous content. The sample from each tube was removed and sectioned into fragments with an approximate volume of $1 \mathrm{~mm}^{3}$, which were conditioned in eppendorfs and fixed in $0.1 \mathrm{M}$ modified Karnovsky solution [2.5\% glutaraldehyde, 2.5\% paraformaldehyde (Sigma-Aldrich Brasil Ltda, São Paulo, SP, Brazil) and 0.1 M phosphate buffer (Sigma-Aldrich Brasil Ltda, São Paulo, SP, Brazil) at $\mathrm{pH} 7.4$ ] for $6 \mathrm{~h}$ at $4^{\circ} \mathrm{C}$.

After three successive washes with $0.1 \mathrm{M}$ phosphate buffer, the post-fixation in osmium tetroxide (Osmium tetroxide crystal $1 \mathrm{~g}^{\circledR}$, Koch Instrumentos Científicos Ltda, São Paulo, SP, Brazil) at $1 \%$, in solution at $0.1 \mathrm{M}$ was accomplished in laminar flow cabinet, during $1 \mathrm{~h}$ at room temperature. After three successive washes, the samples were pre-contrasted with $0.5 \%$ uranyl acetate (Uranyl acetate $25 \mathrm{~g}^{\circledR}$, Koch Instrumentos Científicos Ltda, São Paulo, SP, Brazil) for $12 \mathrm{~h}$ at $4^{\circ} \mathrm{C}$.

Subsequently, the samples were washed for three times with $0.1 \mathrm{M}$ phosphate buffer, and the dehydration process in sequential dilutions of acetone (Acetona $\mathrm{PA}^{\circledR}$, ACS F. Maia Indústria e Comércio Ltda, Cotia, SP, Brazil) was started. Then, the samples were infiltrated in a mixture of acetone with epoxy resin (Epoxy Embedding Kit ${ }^{\circledR}$, Sigma-Aldrich Brasil Ltda, São Paulo, SP, Brazil) and later they were placed in silicone molds, where the inclusion in Epoxy resin was accomplished. The procedures for preparation of the resin, infiltration and polymerization were performed according to manufacturer's instructions.

The samples were incubated in oven at $45^{\circ} \mathrm{C}$ for $12 \mathrm{~h}$ and subsequently at $60^{\circ} \mathrm{C}$ for $36 \mathrm{~h}$ for resin polymerization. The presence of platelets in the semithin sections $(0.25$ to $0.5 \mu \mathrm{m})$ obtained with ultramicrotome (Sorvall MT2-B ultra microtome, Ivan Sorvall INC., Newtown, Conenecticut, USA) and glass razor (Bioslide Technologies, Walnut, CA, USA), was demonstrated by staining with toluidine blue (Azul de toluidina PA 25g ${ }^{\circledR}$, Allkimia Comércio de Materiais para Laboratórios Ltda, Campinas, SP, Brazil). Then, the blocks were trimmed in order to reduce the surface area to be used in confection of the ultrathin sections (80 to $100 \mathrm{~nm}$ thick) obtained in ultramicrotome with diamond razor (Diamond razor ultra $35^{\circ}{ }^{\circledR}$, Diatome, AG, Biel, Switzerland). The slices were 
mounted on copper grids (Copper grid 200 mesh square ${ }^{\circledR}$, Koch Instrumentos Científicos Ltda, São Paulo, SP, Brazil) with three replicates for each sample. Then, each grid was contrasted in a drop of 3\% uranyl acetate for $20 \mathrm{~min}$ at absence of light. Following, the grids were contrasted in drops of $10 \%$ lead citrate (Lead citrate $25 \mathrm{~g}^{\circledR}$, Koch Instrumentos Científicos Ltda, São Paulo, SP, Brazil) over 5 min in $\mathrm{CO}_{2}$-free environment.

After viewing and evaluation of all grids in a transmission electron microscope, the platelet quantifications were accomplished by observing 10 mesh (randomly chosen per grid) in order to generate the percent platelets representing the sample. The meshes were randomly chosen, except those with total absence of tissue cutting, which were not quantified aiming to obtain a better representation of the sample. To avoid duplicate assessment of the meshes, it was used the routine tracking of the program (TIA Software, version 2.1.8, Tecnai, Hillsboro, Oregon, USA), which identifies images that allow to mark the meshes, besides presenting, on screen, the way run through analysis.

The platelets were morphologically classified, according to description by Wurzinger \& Schmid-Schönbein (1990) with some modification, in: 0 (resting): "smooth discs" viewed edge on, therefore lancet-shaped; 1 (state of activation uncertain): round profiles, organelles not centralized; 2 (fully activated): "spiny spheres" with organelles centered; 3 (irreversibly damaged): ballooned, and 4: with aspect of rupture.

The data obtained from morphometry, as referring to platelet morphology (resting, state of activation uncertain, fully activated, irreversibly damaged and with aspect of rupture) were corrected for quantity of the platelets present in PRP previous to activation. This correction was performed by dividing the total platelet number determined in transmission electron microscopy by the total platelet number obtained in PRP, multiplied by the average platelet value obtained in PRP, as considering all animals. This correction of the platelet number was performed in order to minimize the effects caused by differing amounts of cells/ $\mu \mathrm{L}$ in both blood and PRP. This difference was due different physiological condition among animals, but always within the reference limits for the species. For the accomplishment of the statistical analysis from those four animals used in the experiment, the highest value of platelets was adopted for each morphological classification.

For the hematological (hematocrit, hemoglobin, erythrocytes, total leukocytes and platelets) and biochemical (TPP and fibrinogen) variables, the descriptive analysis was performed with minimum and maximum. To verify the frequencies of the differences between the morphological platelet types and between the treatments were due to random, that is independents, the Chi-square test at $5 \%$ significance level was used. Those tests were processed by the software Minitab version 16, 2010 (http://www.minitab.com/products/minitab, State College, PA).

\section{RESULTS}

The values of the hematological and biochemical variables evaluated two weeks before the accomplishment of the experiment were $26-33 \%, 9.3-11.2 \mathrm{~g} / \mathrm{dL}, 6.0-7.0 \times 10^{6}$ cells/ $\mu \mathrm{L}, 6,600-10,500$ cells $/ \mu \mathrm{L}, 198,000-223,000$ cells $/ \mu \mathrm{L}, 7.0-$ $8.0 \mathrm{~g} / \mathrm{dL}$ e $100-400 \mathrm{mg} / \mathrm{dL}$, for packed cell volume, hemoglobin concentration, erythrocytes count, leukocytes count, platelets count, protein concentration and fibrinogen concentration, respectively.

On the day of the PRP obtainment, the platelet count in whole blood of those four animals were 145,000 to 188,000 cells/ $\mu \mathrm{L}$, whereas in PRP were 310,000 to 650,000 cells/ $\mu \mathrm{L}$.

In general observation of the fields in transmission electron microscopy had presence of erythrocytes and polymorphonuclear leukocytes in all treatments. The mononuclear leukocytes were only detected in bovine thrombin-treated samples. Platelet aggregate was occasionally observed in pure PRP (control) and in the samples treated with thrombin associated with $10 \% \mathrm{CaCl}_{2}$.

The platelets maximum values for each classification, as considering the four animals, after correction of platelet number obtained in morphometry can be observed on Table 1 . On the Table 2 are demonstrated the percentages of morphology obtained only to pure PRP and the one activated with $\mathrm{CaCl}_{2}$, since in the treatment with thrombin alone or associated with $10 \% \mathrm{CaCl}_{2}$, there were no platelets with aspects that would fit into classification adopted in this study, as described by Wurzinger \& Schmid-Schönbein (1990).

Among the platelets classified as fully activated $(n=28.50)$ and at rest $(n=70.95)$, a total of $16.50(58 \%)$ and 13.95 (20\%), respectively, were observed in the PRP activated with $10 \% \mathrm{CaCl}_{2}$ as the remainder being in pure PRP. There was an association $(\mathrm{P}=0.03)$ between the morphological platelet type and the treatment.

The figure 1 shows some types of platelet morphology presents in pure PRP and the one activated with $10 \% \mathrm{CaCl}_{2}$. The samples treated with pure bovine thrombin as well as with association of thrombin and $10 \% \mathrm{CaCl}_{2}$ showed platelets with a distinct morphology characterized by irregular form, emission of large filamentous pseudopods, an aspect of rupture and entire granules both in the remaining cytoplasm and in the adjacent extracellular environment. Cellular debris and fibrin were also observed between the platelets (Fig.2).

Table 1. Maximum platelet values obtained from correction of the platelet count in the activated or unactivated platelet-rich plasma (PRP) in each morphological classification adopted for statistical test

\begin{tabular}{lcccc}
\hline $\begin{array}{c}\text { Morphological } \\
\text { classification of the } \\
\text { platelets }\end{array}$ & Pure PRP & $10 \% \mathrm{CaCl}_{2}$ & $\begin{array}{c}\text { Bovine } \\
\text { thrombin }\end{array}$ & $\begin{array}{c}\text { Bovine throm- } \\
\text { bin }+10 \% \mathrm{CaCl}_{2}\end{array}$ \\
\hline 0: resting & 57.00 & 13.95 & 0 & 0 \\
1: state of activation & 68.68 & 37.20 & 0 & 0 \\
$\quad$ uncertain & 12.00 & 16.50 & 0 & 0 \\
2: fully activated & 1.16 & 1.50 & 0 & 0 \\
3: irreversibly da- & & & & \\
$\quad$ maged & 0 & 0 & 215.33 & 94.43 \\
4: aspect of rupture* & 0 \\
* Morphological change found in this study but not reported in the classi- \\
fication adopted.
\end{tabular}

Table 2. Percent platelets in each morphological classification, obtained in the pure platelet-rich plasma (PRP) and the PRP activated with $10 \% \mathrm{CaCl}_{2}$

\begin{tabular}{lcc}
\hline Morphological classification of the platelets & $\begin{array}{c}\text { Pure PRP } \\
(\%)\end{array}$ & $\begin{array}{c}10 \% \mathrm{CaCl}_{2} \\
(\%)\end{array}$ \\
\hline 0: resting & 41 & 20 \\
1: state of activation uncertain & 49 & 54 \\
2: fully activated & 9 & 24 \\
3: irreversibly damaged & 1 & 2
\end{tabular}




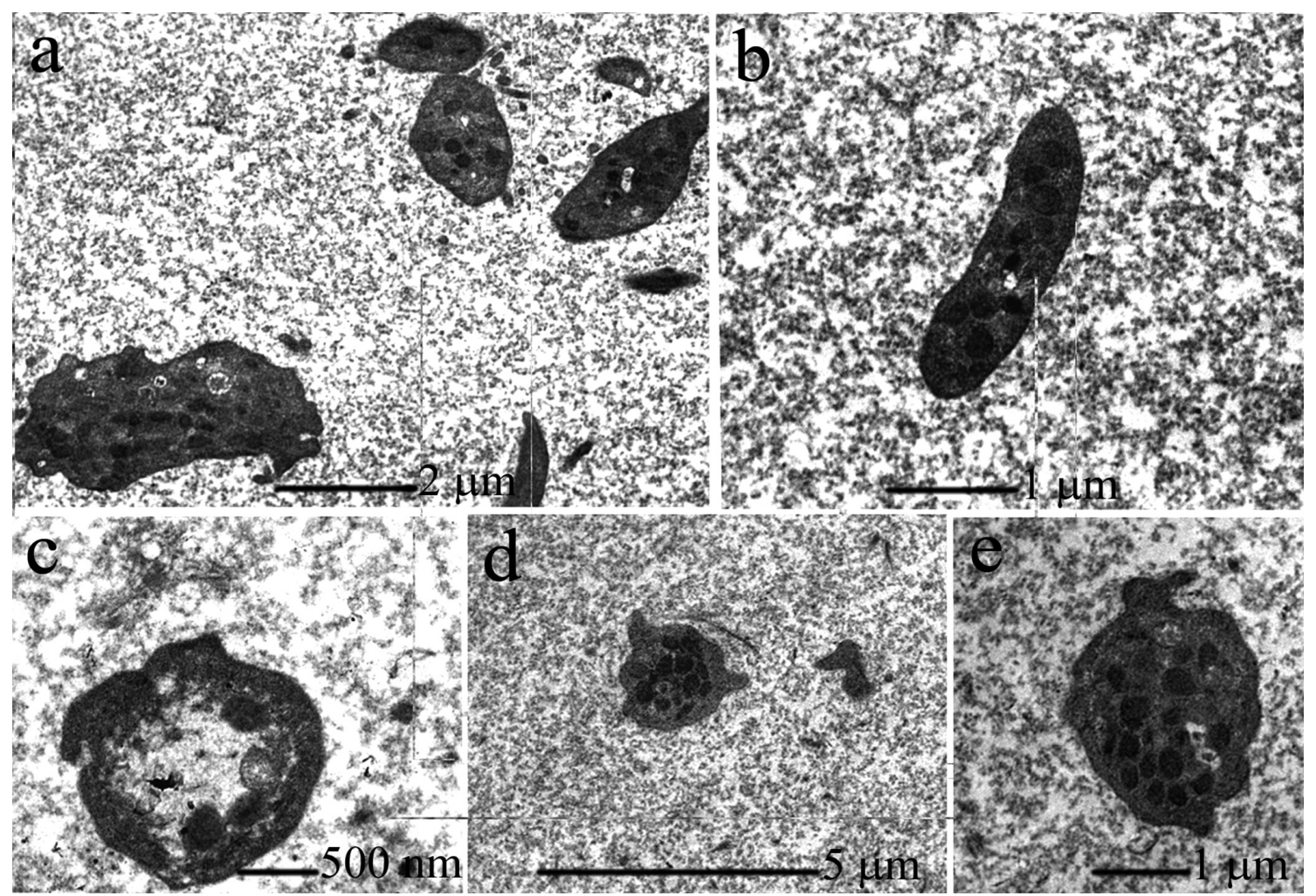

Fig.1. Electronmicrograph showing the platelet aggregation and platelet in state of activation uncertain, with irregular edge and decentralization of the granules (a). Resting platelets, in an oval shape, smooth edges and randomly dispersed granules (b). Irreversibly damaged to platelets, with discoidal shape and migration of organelles to the periphery (c). Fully activated platelets with irregular shape, emission of pseudopods and centralization of granules (d, e).
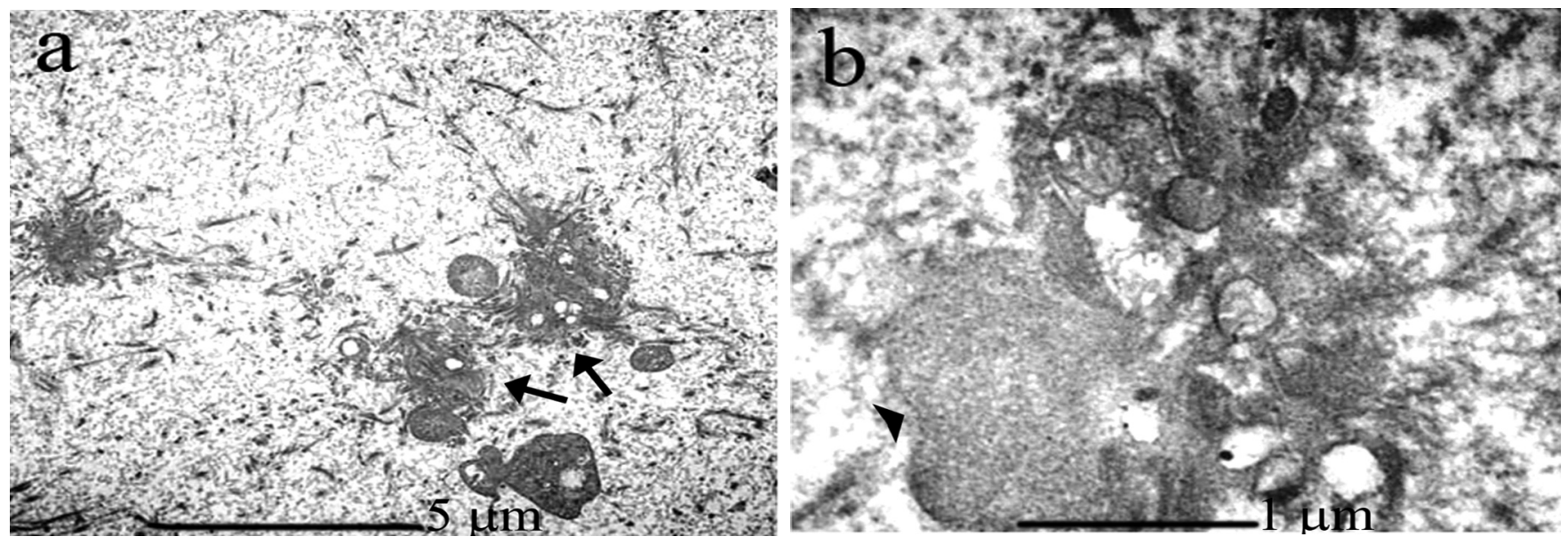

Fig.2. Electronmicrograph of platelets with an aspect of rupture observed in platelet-rich plasma activated with thrombin alone or combined with $10 \% \mathrm{CaCl}_{2}$. Platelet aggregation (arrows), as well as fibrin formation between platelets and cellular debris dispersed in plasma are observed (a). Detail of platelet with cell lysis, with protruding cytoplasm (arrowhead) and intact granules within the cytoplasm and extracellular environment, besides fibrin (b).

\section{DISCUSSION}

The values of the hematological and biochemical variables measured two weeks before the accomplishment of the experiment were within the reference limits for equid species (Kaneko et al. 2008, Grondrin \& Dewitt 2010), therefore indicating the healthiness of the animals.

In PRP, all animals showed platelet counts higher than 300,000 cells $/ \mu \mathrm{L}$, an amount mentioned as appropriate by Anitua et al. (2004).
The presence of the erythrocytes and polymorphonuclear leukocytes observed in all treatments analyzed by transmission electron microscopy can influence the efficiency of the PRP in the injured tissue that will receive the therapy. The expression of the selectin in cellular membrane after occurring its fusion with the membranes of the granules during exocytosis (Larsen et al. 1989, Rinder et al. 1991, Diacovo et al. 1996) may be responsible for the adhesion among platelets, leukocytes and monocytes. However, 
the ideal PRP must not contain polymorphonuclear leukocytes, since those cells can potentiate the physiological pro-inflammatory response in the injured tissue through activation of the adhesion receptors to other cells of the immune system, and secretion of chemokines and cytokines that will promote the cellular differentiation (Woodell-May \& Pietrzak 2008). Additionally, the neutrophils express enzymes which degrade the extracellular matrix, such as the metalloproteinases MMP-8 and MMP-9, and release reactive oxygen species that destroy both the damaged and healthy cells (Scott et al. 2004).

When studying the in vitro adhesion of platelets to leukocytes, Rinder et al. (1991) observed that 93\% monocytes and $82 \%$ polymorphonuclear leukocytes bound to platelets when those platelets were activated by bovine thrombin at final concentration of 0.1 to $0.25 \mathrm{IU} / \mathrm{mL}$, and those percentages were lower in the PRP activated with ADP or without activation. According to the authors, the thrombin promotes enhanced expression of the membrane protein GMP140, that according to Larsen et al. (1989) is a P-selectin responsible for mediating the adhesion of activated platelets to polymorphonuclear and monocyte leukocytes. This fact can explain the observation of mononuclear leukocytes only in the PRP treated with bovine thrombin in the present study, from which the final concentration of $20 \mathrm{IU} / \mathrm{mL}$ was based on pre-establishment protocols of PRP (Waselau et al. 2008) and platelet concentrate activation (Aspenberg \& Virchenko 2004) for use as therapeutic method.

The platelet aggregation, a phenomenon characterized by morphological modification of the platelets after activation, with development of pseudopods that spread in the injured tissue (Everts et al. 2006a), was occasionally observed in the present study, both in pure PRP and the one activated with thrombin associated with $10 \% \mathrm{CaCl}_{2}$. This was an accidental event, which may be due to the presence of free hemoglobin (Wurzinger et al. 1980) or by mechanical stimulation during centrifugation process (Weiss et al. 1998). Although elevated hematocrit can also induce the occurrence of platelet aggregate (Weiss et al. 1998), this hematologic variable should not have influenced the occurrence of the aggregate in this research, since the values of hematocrit were within the reference limits for the species, as already mentioned. Other possible causes are the presence of the fibrinogen, von Willebrand factor (vWf) and adhesive proteins secreted by the platelet granules when platelets are at activated stage, which may account for the formation of bridges between them (Anitua et al. 2004). According to Blair \& Flaumenhaft (2009), those adhesive proteins are responsible for promoting the platelet-platelet interactions.

The platelet activation occurs in order to amplify the inflammatory response to the existing injury, in such a way to promote a faster and effective recovery. However, the excessive activation with uncontrollable formation of platelet aggregates is responsible for a number of thromboembolic events, especially within arteries (Blockmans et al. 1995). In this sense, a maximum care is required during preparation of the PRP, so neither hemolysis nor mixture of the leukocyte or erythrocyte columns with plasma to occur during manipulation of the centrifuged tubes. Despite the overcautious during the PRP-obtainment process, there is always the possibility of human error or contamination during centrifugation.

The pure PRP and the one activated with $10 \% \mathrm{CaCl}_{2}$ allowed the visualization of fully activated platelets with round-shaped, emission of pseudopods and centralized organelles. Those characteristics were also observed in other ultrastructural studies with PRP not pharmacologically activated, in order to evaluate the platelets morphology in vitro, when subjected to shear stress forces in order to mimic the blood flow (Wurzinger et al. 1985, Wurzinger \& Schimid-Schönbein 1990), and in vivo, when exposed to toxins released during overload by grains, used in experimental induction of laminitis with or without previous treatment with nonsteroidal anti-inflammatory drugs, which can inhibit the platelet aggregation (Paes Leme et al. 2006).

In the present study, the difference between treatments in the efficacy of platelet degranulation was shown. Both pure PRP and the PRP activated with $10 \% \mathrm{CaCl}_{2}$ showed a similar pattern, although the non-activated one demonstrated higher amount of platelets as resting. This platelet morphological type is inert, that is it does not exert secretory function, since it does not release growth factors, but can do so when activated by collagen (Blockmans et al. 1995, Camera et al. 1999, Furlan 2002, Everts et al. 2006a) and other substances present in the injured tissue, such as adrenaline and serotonin (Blockmans et al. 1995), fibrin and tissue platelets already activated after injury of the endothelium (Molloy et al. 2003, Lin et al. 2004, Hope \& Saxby 2007). Thus, the pure PRP has high potential for activation and, consequently, degranulation, as depending on degradation and size of lesion.

The pharmacologically not activated PRP also presented a high number of platelets in state of activation uncertain. The ability of those platelets to promote degranulation is not known, but it is possible they could finish their activation process and become fully activated in tissue where PRP will be placed, thereafter releasing the content of its granules by exocytosis.

Platelets irreversibly damaged were observed in the pure PRP and the one activated with $10 \% \mathrm{CaCl}_{2}$. According to Wurzinger \& Schmid-Schönbein (1990), this form is characterized by balloon-shaped degeneration as consequence from influx of the extracellular liquid across the plasmatic membrane not completely integral. The alteration of the membrane could affect the fusion of granules with it, consequently influencing the amount of growth factors released. Thus, this morphology may be considered as inappropriate, when the obtainment of the ideal PRP is proposed.

In the present study, the majority of the fully activated platelets were observed in PRP activated with $10 \% \mathrm{CaCl}_{2}$. The addition of calcium chloride to the platelet-rich component promotes the formation of natural thrombin, as mimicking the physiological process of clot formation, and allows the release of growth factors for a longer period, which could be crucial in the repair and healing of the tissue (Tsay et al. 2005). In those activated platelets, the granules should be ready to undergo degranulation and 
release of growth factors acting on the repair of the lesion (Harrison \& Cramer 1993). When conducting an in vitro study, White et al. (1965) used $0.2 \mathrm{~mL}$ of $\mathrm{CaCl}_{2}$ at $0.025 \mathrm{M}$ $(0.277 \%)$ in order to activate the platelets and stimulate the clot formation in human PRP. The authors investigated the platelet-fibrin relationship in formation of the clots and were able to evidence by ultrastructural evaluation the morphological changes in the activated platelets and their ability to form aggregates.

The addition of thrombin to PRP results into fibrin formation and provokes remarkable morphological changes in platelets, such as the shape change, pseudopods development, centralization and fusion of the granules (De Clerck et al. 1975), and release of their contents (De Clerck et al. 1975, Ouyang \& Qiao 2006). However, the intensity of the platelet activation and the consequent changes in their morphology can be influenced by concentration of the thrombin in PRP, as observed by White \& Krumwiede (1987) in in vitro ultrastructural study of human platelets exposed to different thrombin concentrations. In the present study, the PRP activated with thrombin alone or combined with $10 \%$ $\mathrm{CaCl}_{2}$ showed platelets from which the morphology did not fit into classification adopted that is characterized by an irregular shape, with aspect of rupture and emission of filamentous pseudopods, as generating large cytoplasmic protrusions. Wurzinger et al. (1985) found similar shapes in an in vitro study with PRP exposed to high shearing force (equal or higher than $170 \mathrm{~N} / \mathrm{m}^{2}$ for $113 \mathrm{~ms}$ ) in viscometer.

Despite of the morphological aspect presented by those platelets, the granules could still be observed inside cytoplasmic remnants, as well as in the adjacent region. This does not necessarily result into degranulation and release of the granule contents. This fact may be considered as prejudicial, because the PRP quality is assured by the presence of growth factors in plasma, which are released after exocytosis of the platelet granules. When conducting an in vitro study, De Clerck et al. (1975) observed that before the onset of the clot retraction in human PRP activated with thrombin concentrations above $10 \mathrm{IU} / \mathrm{mL}$, the platelets showed extensive formation of cytoplasmic protrusions with a high tendency to fibrin deposition, which extended to a central area of granular fusion. In addition, with the development of clot retraction, extensive platelet clusters and fibrin were formed, occurring apparently the platelet degranulation. Otherwise, White et al. (1965) also observed this morphology, when evaluating the platelet-fibrin relationship in human blood clots after addition of $0.2 \mathrm{~mL}$ of $\mathrm{CaCl}_{2}$ at $0.025 \mathrm{M}(0.277 \%)$, and called them as rosette formations.

The addition of small amounts of the human thrombin diluted into calcium gluconate solution and placed into PRP promotes immediate clotting (Kitoh et al. 2004), so changing the consistency of the liquid PRP to gel (Ouyang \& Qiao 2006), as hampering its application by needles (Kitoh et al. 2004). In such cases, the simultaneous administration without prior mixing is a good alternative (Kitoh et al. 2004), since it seems to improve the platelet degranulation and possibly the release of growth factors, besides promoting the retention of platelets in the lesion (Waselau et al. 2008).
This technique was used by several authors (Aspenberg \& Virchenko 2004, Kitoh et al. 2004, Sutter et al. 2004, Everts et al. 2006b, Gandhi et al. 2006, Murray et al. 2006, Waselau et al. 2008, Woodell-May \& Pietrzak 2008).

On the other hand, some importance should be given to use of the bovine thrombin as platelet-activating agent, since this substance can cause the development of the anti-thrombin, anti-factor $\mathrm{V}$ and anti-factor XI antibodies, therefore resulting into problems ranging from intense bleeding to autoimmune syndromes (Sánchez et al. 2003, Lawson 2006). An in vitro study carried out by Fufa et al. (2008) revealed a rapid and accentuated contraction of the gelatinous clot, when using bovine thrombin as activating agent of PRP obtained from human blood, which can inhibit the fulfilling and healing of wounds.

According to Marx (2004) and Pietrzak \& Eppley (2005), the growth factors are actively secreted from $\alpha$-granules during the first $10 \mathrm{~min}$ of clotting, and more than $95 \%$ presynthesized factors are released at the first hour (Kevy \& Jacobson 2001). Moreover, the secreted ones may remain in the fibrin clot, as being slowly released during the degradation of the clot (Woodell-May \& Pietrzak 2008). This is likely to occur in the platelet-rich components immediately after their preparation. Thus, the immediate use of the concentrate of platelets (Roukis et al. 2006) and PRP (Marx 2001 2004) after their preparation are recommended, as the maximum time for utilization being $8 \mathrm{~h}$, when their stability loss may finally occurs, as well as the deficiency in the secretory proteins that were expressed (Pietrzak \& Eppley 2005). In the present study, after administration of the activating agent, the PRP was placed in oven, since the objective was the optimization of degranulation (Zimmermann et al. 2003, Argüelles et al. 2006, Maia et al. 2009a,b), which is essential to implementation of the ultrastructural study, from which the purpose was to indicate the platelet activator that would be most suitable to PRP therapeutic use.

Although it is known that PRP must be activated for platelets to release the contents of their granules and form clots, as providing a vehicle to contain the secreted proteins and maintain their presence in the wound site (Pietrzak \& Eppley 2005), there is controversy about the need or not for this activation prior to its application, particularly with thrombin. Despite the importance of using the activating agents, it is known that the mechanical stress caused by centrifugation during preparation of the platelet-rich plasma can activate some platelets (Gonshor 2002, Landi \& Marques Júnior 2003), which explains the presence of this morphological type in pure PRP evaluated in the present study. In this sense, several experiments have already used the pure PRP, that is, without the previous addition of pharmacological activating agents, in researches conducted both in horses (Smith et al. 2006, Schnabel et al. 2007, Bosch et al. 2009, McCarrel \& Fortier 2009) and humans (Mishra \& Pavelko 2006, Kajikawa et al. 2008).

Because there are no available morphological studies of the platelets found in PRP as comparing different activating agents, the data obtained in this study could not be compared. Additionally, the hypothesis was not confirmed, since the morphology of platelets seen in the thrombin- 
-activated PRP was not characteristics of degranulation. Taking into account the fully activated platelets are more likely to perform degranulation, with consequent release of growth factors, a PRP presenting higher proportion of this morphology is considered as the most appropriate one. In the present study, the ultrastructural analysis revealed the PRP activated with $10 \% \mathrm{CaCl}_{2}$ to be ideal, because it showed the highest quantity of platelets classified as fully activated. However, when a more fluid PRP, which would be easily administrated in tendons and ligaments, is necessary, the use of $10 \% \mathrm{CaCl}_{2}$ as activator may not be viable, since its addition promotes the formation of a gel. For this application, it is recommend the use of pure PRP, which was the second treatment with the highest percentage of fully activated platelets in this research. In addition, the resting platelets, also present in pure PRP, may undergo activation in the tissue to be administered, thereby occurring the release of the growth factors present in platelet granules. By the other hand, as there may be loss of stability and deficiency in the expressed secretory proteins in PRP when not quickly used, it is important that ultrastructural studies to be conducted immediately after its preparation, as well as researches that quantify the growth factors in PRP pharmacologically activated or not.

\section{CONCLUSIONS}

This study allowed to conclude that the $10 \%$ calcium chloride solution is an activating substance suitable for platelets.

However, the platelet-rich plasma can be used without prior activation by pharmacological agents, since it presents a high percentage of fully activated platelets after routine procedures for its obtainment.

Acknowledgements.- To FAPEMIG for the financial support, to CAPES and CNPq for granting the mastership and undergraduate research scholarships, respectively, as well as to the Núcleo de Microscopia e Microanálise of the Universidade Federal de Viçosa and to the Centro de Microscopia of the Universidade Federal de Minas Gerais for making available the laboratory.

\section{REFERENCES}

Alsousou J., Thompson M., Hulley P., Noble A. \& Willett K. 2009. The biology of platelet-rich plasma and its application in trauma and orthopaedic surgery. J. Bone Joint Surg. Brit. 91b:987-996.

Anitua E., Andia I., Ardanza B., Nurden P. \& Nurden A.T. 2004. Autologous platelet as a source of proteins for healing and tissue regeneration. Thromb. Haemost. 91:4-15.

Argüelles D., Carmona J.U., Climent F., Muñoz E. \& Prades M. 2008. Autologous platelet concentrates as a treatment for musculoskeletal lesions in 5 horses. Vet. Rec. 162:208-211.

Argüelles D., Carmona J.U., Pastor J., Iborra A., Viñals L., Martínez P., Bach E. \& Prades M. 2006. Evaluation of single and double centrifugation tube methods for concentrating equine platelets. Res. Vet. Sci. 81:237-245.

Aspenberg P. \& Virchenko 0. 2004. Platelet concentrate injection improves Achilles tendon repair in rats. Acta Orthop. Scand. 75:93-99.

Blair P. \& Flaumenhaft R. 2009. Platelet $\alpha$-granules: basic biology and clinical correlates. Blood Rev. 23:177-189.

Blockmans D., Deckmyn H. \& Vermylen J. 1995. Platelet activation. Blood Rev. 9:143-156.
Bosch G., van Schie H.T.M., Groot M.W., Cadby J.A., van De Lest C.H.A., Barneveld A. \& van Weeren P.R. 2009. Effects of platelet-rich plasma on the quality of repair of mechanically induced core lesions in equine superficial digital flexor tendons: a placebo-controlled experimental study. J. Orthop. Res. 28:211-217.

Camera M., Giesen P.L., Fallon J., Aufiero B.M., Taubman M., Tremoli E. \& Nemerson Y. 1999. Cooperation between VEGF and TNF-alpha is necessary for exposure of active tissue factor on the surface of human endothelial cells. Arterioscler. Thromb. Vasc. Biol. 19:531-537.

Carmona J.U., Argüelles D., Climent F. \& Prades M. 2007. Autologous platelet concentrates as a treatment of horses with osteoarthritis: A preliminary pilot clinical study. J. Equine Vet. Sci. 27:167-170.

De Clerck F., Borges M., Gaetano G. \& Vermylen J. 1975. Dissociation of clot retraction from platelet granule fusion and degranulation: an ultrastructural study of Reptilase - human platelet-rich plasma clots. Brit. J. Haematol. 29:341-348.

De Mos M., Van Der Windt A.E., Jahr H., Van Schie H.T.M., Weinans H., Verhaar J.A.N. \& Van Osch G.J.V.M. 2008. Can platelet-rich plasma enhance tendon repair? A cell culture study. Am. J. Sports Med. 36:1171-1178.

De Vos R.J., Weir A., van Schie H.T.M., Bierma-Zeinstra S.M.A., Verhaar J.A.N., Weinans H. \& Tol J.L. 2010. Platelet-rich plasma injection for chronic Achilles tendinopathy: a randomized controlled trial. J. Am. Med. Assoc. 303:144-149.

Diacovo T.G., Puri K.D., Warnock R.A., Springer T.A. \& Andrian U.H. 1996. Platelet-Mediated lymphocyte delivery to high endotelial venules. Science 273:252-255.

Escolar G. \& White J.G. 1991. The platelet open canalicular system: a final common pathway. Blood Cells 17:467-485.

Everts P.A.M., Knape J.T.A., Weibrich G., Schönberger J.P.A.M., Hoffmann J., Pverdevest E.P., Box H.A.M. \& van Zundert A. 2006a. Platelet-rich plasma and platelet gel: a review. J. Extra Corpor. Techn. 38:174-187.

Everts P.A.M., Mahoney C.B., Hoffmann J.J.M.L., Schönberger J.P., Box H.A.M., Van Zundert A. \& Knape J.T.A. 2006b. Platelet-rich plasma preparation using three devices: implications for platelet activation and platelet growth factor release. Growth Factors 24:165-171.

Filgueiras R.R. 2008. Uso de condrócitos heterólogos cultivados na reparação de falhas osteocondrais produzidas no joelho de coelho. Dissertação de Mestrado em Medicina Veterinária, Universidade Federal de Viçosa, Viçosa, MG. 68p.

Foster T.E., Puskas B.L., Madelbaum B.R., Gerhardt M.B. \& Rodeo S.A. 2009. Platelet-rich plasma: from basic science to clinical applications. Am. J. Sports Med. 37:2259-2272.

Frechette J.P., Martineau I. Gagnon G. 2005. Platelet-rich plasmas: growth factor content and roles in wound healing. J. Dent. Res. 84:434-439.

Freson K., Labarque V., Thys C., Wittevrongel C. \& van Geet C. 2007. What's new in using platelet research? To unravel thrombopathies and other human disorders. Eur. J. Pediatr. 166:1203-1210.

Fufa D., Shealy B., Jacobson M., Sherwin K., Murray M.M. 2008. Activation of platelet-rich plasma using type I collagen. J. Oral Maxillofac. Surg. 66:684-690.

Furlan M. 2002. Sticky and promiscuous plasma proteins maintain the equilibrium between bleeding and thrombosis. Swiss Med. Wkly. 132:181-189.

Gandhi A., Doumas C., O'connor J.P., Parsons J.R. \& Lin S.S. 2006. The effects of local platelet rich plasma delivery on diabetic fracture healing. Bone 38:540-546

Giacco F., Perruolo G., D’agostino E., Fratellanza G., Perna E., Misso S., Saldalamacchia G., Oriente F., Fiory F., Miele C., Formisano S., Beguinot F. \& Formisano P. 2006. Thrombin-activated platelets induce proliferation of human skin fibroblasts by stimulating autocrine production of insulin-like growth factor-1. FASEB J. 20:1763-1772.

Gimeno F.L., Gatto S., Ferro J., Croxatto J.O. \& Gallo J.E. 2006. Preparation of platelet-rich plasma as a tissue adhesive for experimental transplantation in rabbits. Thromb. J. 4:1-7. doi: 10.1186/1477-9560-4-1 
Gonshor A. 2002. Technique for producing platelet-rich plasma and platelet concentrate: background and process. Int. J. Periodontics Restorative Dent. 22:547-557.

Grondin T.M. \& Dewitt S.F. 2010. Normal hematology of the horse and donkey, p.821-828. In: Weiss D.J. \& Wardrop K.J. (Eds), Schalm's Veterinary Hematology. $6^{\text {th }}$ ed. Blackwell Publishing, Ames.

Harrison P. \& Cramer E.M. 1993. Platelet alpha-granules. Blood Rev. 7:52-62.

Hope M. \& Saxby T.S. 2007. Tendon healing. Foot Ankle Clin. North Am. 12:553-567.

Kajikawa Y., Morihara T., Sakamoto H., Matsuda K., Oshima Y., Yoshida A., Nagae M., Arai Y., Kawata M. \& Toshikazu K. 2008. Platelet-rich plasma enhances the initial mobilization of circulation-derived cells for tendon healing. J. Cell Physiol. 215:837-845.

Kaneko J.J., Harvey J.W. \& Bruss M.L. 2008. Appendix I SI units, p.916. In: Kaneko J.J., Harvey J.W. \& Bruss M.L. (Eds), Clinical Biochemistry of Domestic Animals. $6^{\text {th }}$ ed. Academic Press, Amsterdam.

Kevy S. \& Jacobson M. 2001. Preparation of growth factors enriched autologous platelet gel. Proc. $27^{\text {th }}$ Annual Meeting of the Society for Biomaterials, St Paul, Minnesota, p.262. (Abstract)

Kitoh H., Kitakoji T., Tsuchiya H., Mitsuyama H., Nakamura H., Katoh M. \& Ishiguro N. 2004. Transplantation of marrow-derived mesenchymal steam cell and platelet-rich plasma during distraction osteogenesis: A preliminary result of three cases. Bone 35:892-898.

Landi E.P. \& Marques Júnior J.F.C. 2003. Caracterização da ativação plaquetária nos concentrados de plaquetas por citometria de fluxo. Revta Bras. Hematol. Hemoter. 25:39-46.

Larsen E., Celi A., Gilbert G.E., Furie B.C., Erban J.K., Bonfanti R., Wagner D.D. \& Furie B. 1989. PADGEM protein: a receptor that mediates the interaction of activated platelets with neutrophils and monocytes. Cell 59:305-312.

Lawson J.H. 2006. The clinical use and immunologic impact of thrombin in surgery. Semin. Thromb. Hemost. 32:98-110.

Lin T.W., Cardenas L. \& Soslowsky L.J. 2004. Biomechanics of tendon injury and repair. J. Biomech. 37:865-877.

Maia L., Souza M.V., Alves G.E.S., Ribeiro Júnior J.I., Oliveira A.C., Zandim B.M. \& Silva Y.F.R.S. 2009a. Plasma rico em plaquetas no tratamento de tendinite induzida em equinos: avaliação ultra-sonográfica. Pesq. Vet. Bras. 29:241-245.

Maia L., Souza M.V., Ribeiro Júnior J.I., Oliveira A.C., Alves G.E.S., Benjamin L.A., Silva Y.F.R.S., Zandim B.M. \& Moreira J.C.L. 2009b. Platelet-rich plasma in the treatment of induced tendinopathy in horses: histologic evaluation. J. Equine Vet. Sci. 29:618-623.

Marx R.E. 2001. Platelet-rich plasma (PRP): what is PRP and what is not PRP? Implant. Dent. 10:225-228.

Marx R.E. 2004. Platelet-rich plasma: evidence to support its use. J. Oral Maxillofac. Surg. 62:489-496.

McCarrel T. \& Fortier L. 2009. Temporal growth factor release from platelet-rich plasma, trehalose lyophilized platelets, and bone marrow aspirate and their effect on tendon and ligament gene expression. J. Orthop. Res. 27:1033-1042.

Mishra A. \& Pavelko T. 2006. Treatment of chronic elbow tendinosis with buffered platelet-rich plasma. Am. J. Sports Med. 34:1774-1778.

Molloy T., Wang Y. \& Murrell G.A.C. 2003. The roles of growth factors in tendon and ligament healing. Sports Med. 33:381-394.

Monteiro S.O., Lepage O.M. \& Theoret C.L. 2009. Effects of platelet-rich plasma on the repair of wounds on the distal aspect of the forelimb in horses. Am. J. Vet. Res. 70:277-282.

Murray M.M., Spindler K.P., Abreu E., Muller J.A., Nedder A., Kelly M., Frino J., Zurakowski D., Valenza M., Snyder B.D. \& Connolly S.A. 2007. Collagen-platelet rich plasma hydrogel enhances primary repair of the porcine anterior cruciate ligament. J. Orthop. Res. 25:81-91.

Murray M.M., Spindler K.P., Devin C., Snyder B.S., Muller J., Takahashi M., Ballard P., Nanney L.B. \& Zurakowski D. 2006. Use of collagen-platelet rich plasma scaffold to stimulate healing of a central defect in the canine ACL. J. Orthop. Res. 24:820-830.
Ouyang X. \& Qiao J. 2006. Effect of platelet-rich plasma in the treatment of periodontal intrabony defects in humans. Chin. Méd. J. 119:1511-1521.

Paes Leme F.O., Wurzinger L.J., Vasconcelos A.C. \& Alves G.E.S. 2006. Ativação de plaquetas de equinos com laminite induzida e tratados com ketoprofeno, fenilbutazona e flunixin meglumina. Arq. Bras. Med. Vet. Zootec. 58:149-157.

Pietrzak W.S. \& Eppley B.L. 2005. Platelet rich plasma: biology and new technology. J. Craniofac. Surg. 16:1043-1054.

Pretorius E., Briedenhann S., Marx J., Smit E., Merwe C.V.D., Pieters M. \& Franz C. 2007. Ultrastructural comparison of the morphology of three different platelet and fibrin fiber preparations. Anat. Rec. 290:188198.

Reed G.L. 2004. Platelet secretory mechanisms. Semin. Thromb. Hemost. 30:441-450.

Rees H.M. \& Ecker E.E. 1923. An improved method for counting blood platelets. J. Am. Med. Assoc. 80:621-622.

Rendu F. \& Brohard-Brohn B. 2001. The platelet release reaction: granules' constituents, secretion and functions. Platelets 12:261-273.

Rinder H.M., Bonan J.M., Ault K.A. \& Smith B.R. 1991. Activated and unactivated platelet adhesion to monocytes and neutrophils. Blood 78:17601769.

Roukis T.S., Zbonis T. \& Tiernan B. 2006. Autologous platelet-rich plasma for wound and osseous healing: a review of the literature and commercially available products. Adv. Ther. 23:218-237.

Sánchez A.R., Sheridan P.J. \& Kupp L.I. 2003. Is platelet-rich plasma the perfect enhancement factor? A current review. Int. J. Oral Maxillofac. Implants 18:93-103.

Schick P.K. \& Yu B.P. 1974. The role of platelet membrane phospholipids in the platelet release reaction. J. Clin. Invest. 54:1032-1039.

Schnabel L.V., Mohammed H.O., Miller B.J., McDermott W.G., Jacobson M.S., Santangelo K.S. \& Fortier L.A. 2007. Platelet Rich Plasma (PRP) enhances anabolic gene expression patterns in flexor digitorum superficialis tendons. J. Orthop. Res. 25:230-240.

Scott A., Khan K.M., Roberts C.R., Cook J.L. \& Duronio V. 2004. What do we mean by the term "inflammation"? A contemporary basic science update for sports medicine. Brit. J. Sports Med. 38:372-380.

Silva S.B., Ferrigno C.R.A., Sterman F.A., Baccarin D.C.B., Yazbek K.V.B., Muramoto C. \& Amaku M. 2007. Plasma rico em plaquetas combinado a hidroxiapatita na formação do calo ósseo em fraturas induzidas experimentalmente no rádio de cães. Ciência Rural 37:1045-1051.

Sims P.J., Faioni E.M., Wiedmer T. \& Shattil S.J. 1988. Complement proteins $\mathrm{C} 5 \mathrm{~b}-9$ cause release of membrane vesicles from the platelet surface that are enriched in the membrane receptor for coagulation factor Va and express prothrombinase activity. J. Biol. Chem. 263:1820518212.

Smith J.J., Ross M.W. \& Smith R.K.W. 2006. Anabolic effects of acellular bone marrow, platelet rich plasma, and serum on equine suspensory ligament fibroblasts in vitro. Vet. Comp. Orthop. Traumatol. 19:43-47.

Sutter W.W., Kaneps A.J. \& Bertone A.L. 2004. Comparison of hematologic values and transforming growth factor-beta and insulin-like growth factor concentrations in platelet concentrates obtained by use of buffy coat and apheresis methods from equine blood. Am. J. Vet. Res. 65:924-930.

Tsay R.C., Vo J., Burke A., Eisig S.B., Lu H.H. \& Landesberg R. 2005. Differential growth factor retention by platelet-rich plasma composites. J. Oral Maxillofac. Surg. 63:521-528.

Vendramin F.S., Franco D. \& Franco T.R. 2009. Método de obtenção do gel de plasma rico em plaquetas autólogo. Revta Bras. Cir. Plast. 24:212-218.

Virchenko 0. \& Aspenberg P. 2006. How can one platelet injection after tendon injury lead to a stronger tendon after 4 weeks. Acta Orthop. 77:806-812.

Waselau M., Sutter W.W., Genovese R.L. \& Bertone A.L. 2008. Intralesional injection of platelet-rich plasma followed by controlled exercise for treatment of midbody suspensory ligament desmitis in Standardbred racehorses. J. Am. Vet. Med. Assoc. 232:1515-1520. 
Weiss D.J., Evanson O.A., McClenahan D., Fagliari J. \& Walcheck B. 1998. Shear-induced platelet activation and platelet-neutrophil aggregate formation by equine platelets. Am. J. Vet. Res. 59:1243-1246.

White J.G., Krivit W. \& Vernier R. 1965. The platelet-fibrin relationship in human blood clots: an ultrastructural study utilizing ferritin-conjugated anti-human fibrinogen antibody. Blood 5:241-257.

White J.G. \& Krumwiede M. 1987. Further studies of the secretory pathway in trombin-stimulated human platelets. Blood 69:1196-1203.

Woodell-May J.E. \& Pietrzak W.S. 2008. Platelet-Rich plasma in orthopedics, p.547-568. In: Pietrzak W.S. (Ed.), Orthopedic Biology and Medicine: musculoskeletal tissue regeneration, biological materials and methods. Hamana Press, Totowa.
Wurzinger L.J., Blasberg P. \& Schmid-Schönbein H. 1980. Hemolysis and in vitro thrombus formation, p.529-533. In: Stoltz J.F. \& Drouin P. (Eds.), Hemorheology and Diseases. Doin, Paris.

Wurzinger L.J., Opitz R., Blasberg P. \& Schimid-Schonbein H. 1985. Platelet and coagulation parameters following millisecond exposure to laminar shear stress. Thromb. Haemost. 54:381-386.

Wurzinger L.J. \& Schmid-Schönbein H. 1990. The role of fluid dynamics in triggering and amplifying haemostatic reactions in thrombogenesis. Monogr. Atheroscler. 15:215-226.

Zimmermann R., Arnold D., Strasser E., Ringwald J., Schlegel A., Wiltfang J. \& Eckstein R. 2003. Sample preparation technique and white cell content influence the detectable levels of growth factors in platelet concentrates. Vox Sang. 85:283-289. 